\title{
Determinação Pré-natal do Sexo Fetal por meio da Análise de DNA no Plasma Materno
}

\author{
Prenatal Fetal Gender Determination by Analysis of DNA from Maternal Pasma \\ José Eduardo Levi ${ }^{1,}$, Silvano Wendel ${ }^{1,2}$, Deise Tihe Takaoka ${ }^{2}$
}

\section{RESUMO}

\begin{abstract}
Objetivo: avaliar um novo método de determinação do sexo fetal pela análise de DNA obtido do plasma materno.

Métodos: sangue periférico $(10 \mathrm{~mL})$ foi coletado de mulheres grávidas em diferentes idades gestacionais. O plasma foi separado e o DNA isolado do mesmo foi submetido à reação em cadeia da polimerase (PCR) com oligonucleotídeos iniciadores derivados do gene DYS14 específico do cromossomo $Y$.

Resultados: foram analisadas amostras de 212 pacientes. Oresultado da PCR foi comparado ao sexo determinado pela ultra-sonografia e/ ou do nascimento. Houve concordância em 209 das 212 pacientes. Nos 3 casos discordantes a PCR apontou resultado feminino, sendo as três amostras coletadas antes da $8^{a}$ semana de gravidez.

Conclusão: o método de PCR desenvolvido para a determinação do sexo fetal possui excelente sensibilidade e especificidade, permitindo seu uso rotineiro. O resultado de sexo masculino possui maior confiabilidade que o feminino, principalmente em idade gestacional precoce. Novas aplicações para o DNA fetal no plasma materno estão sendo pesquisadas, permitindo no futuro o diagnóstico não invasivo de uma série de doenças.
\end{abstract}

PALAVRAS-CHAVE: PCR - Reação em cadeia da polimerase. DNA plasmático. Sexo fetal.

\section{Introdução}

O desenvolvimento e aprimoramento de técnicas não invasivas de diagnóstico são objetivos constantemente almejados na medicina. As técnicas de diagnóstico por imagem representam uma face muito importante deste processo, e os métodos laboratoriais baseados em amostras biológicas uma segunda vertente.

O diagnóstico pré-natal de uma série de intercorrências requer o uso de métodos invasivos, como a realização de biópsia de vilosidade coriônica ou a obtenção de líquido amniótico, com

\footnotetext{
${ }^{1}$ Banco de Sangue, Hospital Sírio Libanês, São Paulo/SP ${ }^{2}$ Centro de Imunologia e Imunogenética, São Paulo/SP Correspondência:

José Eduardo Levi

Centro de Imunologia e Imunogenética

Rua Peixoto Gomide, $515,12^{\circ}$ andar - Bela Vista

01409-001 - São Paulo - SP

Fone: (11) 3285-5999 - Fax: (11) 3284-5315

e-mail: biologia@cii-laboratorio.com.br
}

risco significativo de perda do feto. Nesse contexto, técnicas não invasivas de amostragem de células fetais têm sido intensamente pesquisadas há muitas décadas ${ }^{1}$.

Em 1989, Lo et al. ${ }^{2}$ demonstraram ser factivel a análise destas células fetais presentes na circulação materna por método de biologia molecular, a reação em cadeia de polimerase (PCR). O isolamento de células fetais da circulação materna é tecnicamente bastante complexo, sendo ainda hoje pouco realizado ${ }^{3}$, aumentando o interesse por técnicas que prescindam do isolamento das células fetais.

Alguns anos mais tarde, pesquisadores na área de oncologia demonstraram a existência de DNA tumoral livre (cell-free) no plasma de pacientes $^{4}$. Estes achados tiveram grande repercussão e estimularam inúmeras pesquisas que comprovaram a presença do DNA tumoral em diferentes tipos de neoplasia, sendo atualmente empregadas no diagnóstico precoce de recidiva e na avaliação do prognóstico ${ }^{5}$. 
Baseados nestes dados, em 1997 Lo et al. ${ }^{6}$. demonstraram fenômeno análogo, a presença de DNA fetal no plasma de mulheres grávidas. Diversos grupos reproduziram estes achados, demonstrando claramente a superioridade prática do DNA fetal plasmático em relação às preparações de células fetais isoladas do sangue materno. Além disso, o isolamento do DNA fetal a partir do plasma materno é relativamente fácil, barato e permite o processamento simultâneo de muitas amostras. De fato, a análise quantitativa do DNA fetal presente no plasma demonstrou que este pode compor até 3-4\% do DNA total, ao passo que as células fetais podem estar presentes no sangue materno numa proporção igual ou inferior a 1:100.000 células maternas? ${ }^{7}$.

A maior parte dos grupos utilizou como marcador de DNA fetal, por motivos práticos, seqüências do cromossomo $\mathrm{Y}$ em grávidas de fetos masculinos. Uma vez comprovada a reprodutibilidade e sensibilidade do método, outros alvos estão sendo investigados, entre estes destaca-se a determinação do genótipo $\mathrm{Rh}(\mathrm{D})^{8}$, a $\beta$-talassemia ${ }^{9}$, a acondroplasia ${ }^{10}$ e até a síndrome de Down ${ }^{11}$.

Os trabalhos mais recentes já utilizam técnicas mais modernas de PCR, baseadas em equipamentos de detecção em tempo real (real-time $P C R)$, atingindo niveis mais altos de sensibilidade e menor risco de contaminação, devido ao fato de o formato fechado da reação evitar manipulações analiticas do amplicon ${ }^{12}$.

Neste trabalho procuramos desenvolver e adaptar uma técnica de PCR convencional para determinação do sexo fetal pela análise do plasma materno, e buscamos avaliar a sensibilidade e especificidade deste método em uma casuística de 212 mulheres grávidas em diferentes idades gestacionais.

\section{Pacientes e Métodos}

Este foi um estudo prospectivo não randomizado. As pacientes interessadas em participar do estudo foram encaminhadas ao Banco de Sangue do Hospital Sírio Libanês de São Paulo, SP, onde lhes era apresentado o termo de consentimento livre e esclarecido (TCLE), contendo uma série de informações sobre o teste. Havendo concordância, a paciente assinava o TCLE e, logo após, uma amostra de $10 \mathrm{~mL}$ de sangue periférico era coletada. Este estudo foi aprovado pelo Comitê de Ética em Pesquisa do Hospital Sírio Libanês (CEPesq, protocolo 2003/05).

O sangue foi coletado em tubos PPT (Plasma Preparation Tube, Beckton-Dickinson, São Paulo, Brasil) e centrifugado por 10 minutos a $1.100 \mathrm{~g}$ (temperatura ambiente). Estes tubos são próprios para análises por métodos moleculares já que contém EDTA como anticoagulante na forma sólida, não havendo, portanto, diluição da amostra, o que pode acarretar erros de estimativa de carga viral, por exemplo, já que os tubos convencionais usam anticoagulantes líquidos que podem levar a uma diluição de até $15 \%$ da amostra. Após a centrifugação os tubos eram armazenados a $4^{\circ} \mathrm{Ce}$ encaminhados ao laboratório em até 48 horas. No laboratório fez-se o isolamento do DNA em duplicatas de $140 \mu \mathrm{L}$ de plasma, empregando-se o QIAamp Blood Mini Kit da Qiagen (Chattlesworth, CA, EUA). Neste método o plasma é submetido a uma lise enzimática com proteinase $\mathrm{K}$, subseqüentemente é tratado com um agente caotrópico, o hidrocloreto de guanidina, e este lisado é finalmente passado através de uma coluna de sílica, que possue afinidade por ácidos nucléicos. Após sucessivas lavagens o DNA/RNA aderido à sílica é eluído com tampão adequado, provido no kit. Fizemos a eluição com $75 \mu \mathrm{L}$ de tampão, portanto cada microlitro de eluato corresponde a aproximadamente $2 \mu \mathrm{L}$ de plasma.

As aliquotas de DNA isolado foram submetidas à reação de PCR empregando-se os primers Y7/Y8 que amplificam um fragmento de 198 pares de bases da seqüência cópia-única e específica do cromossomo Y DYS $14^{13}$. Cada extrato foi amplificado também em duplicata. Portanto, cada amostra corresponde a quatro reações de PCR (Figura 1). Como controle, todos os extratos foram também submetidos à amplificação de um fragmento de 268 pares de bases do gene da $\beta$-globina huma$\mathrm{na}^{14}$. Os produtos de PCR foram observados por meio de eletroforese em gel de agarose $2 \%$ corado com brometo de etídio e as imagens foram digitalizadas e armazenadas em computador. $\mathrm{O}$ padrão de peso molecular 100 bp ladder (Invitrogen, São Paulo, Brasil) foi utilizado para averiguar-se o tamanho do produto amplificado. A presença de 3 ou 4 bandas correspondendo ao fragmento de 198 pares de bases do cromossomo $\mathrm{Y}$ foi interpretada como indicativo de feto do sexo masculino.

Os resultados foram reportados às pacientes que assim desejaram, por contato telefônico, fax ou e-mail. 


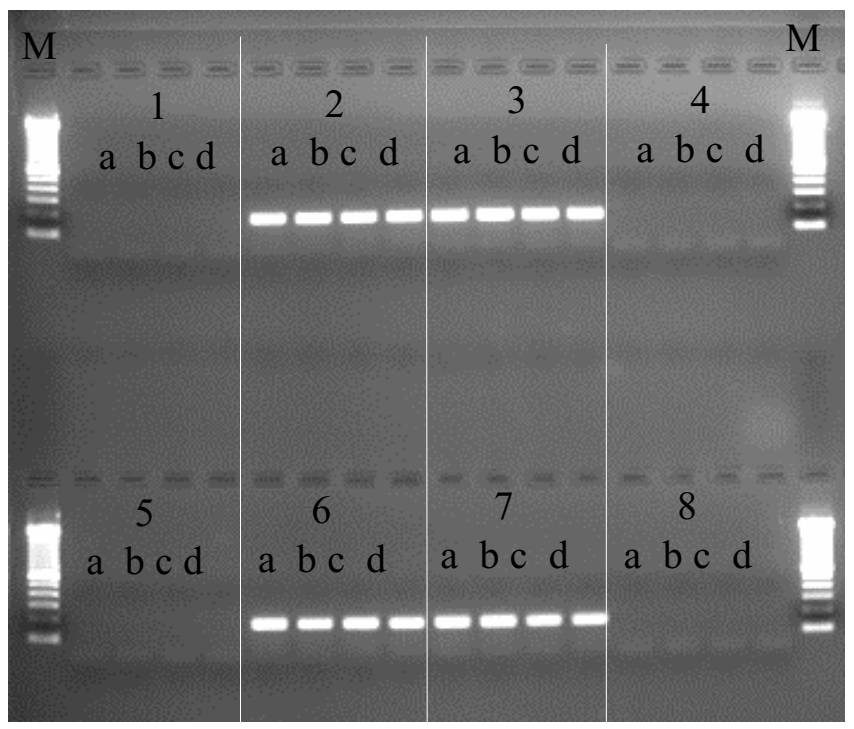

Figura 1 - Reação de PCR para fragmento do cromossomo Y a partir de DNA isolado do plasma materno.

Eletroforese de produtos de reação de PCR para fragmento de 198 pares de bases do gene DYS14 em gel de agarose $2 \%$ corado com brometo de etídio.

1 a 8 - amostras de 8 pacientes do estudo. a, b, c e d - quadruplicatas de PCR de cada amostra. $M=$ marcador de peso molecular, 100-bp ladder (Invitrogen São Paulo, Brasil). As amostras 2, 3, 6 e 7 amplificaram a banda de 198 pares de bases, indicando gravidez de feto do sexo masculino.

\section{Resultados}

Entre as 212 amostras coletadas houve 97 resultados de sexo masculino e 115 de sexo feminino. Apenas três amostras apresentaram resultado errado, todas coletadas de grávidas com menos de 8 semanas de idade gestacional. Nestes 3 casos, o PCR apontou ausência de amplificação (= sexo feminino) e, posteriormente, verificou-se tratar de gravidez de feto masculino. Todos os outros 209 resultados foram corretos, levando a índice de acerto de $100 \%$ em idade gestacional de mais de 8 semanas (Tabela 1). Amostras que apresentaram 1 ou 2 reações positivas, das 4 executadas, foram submetidas à repetição do processo, o que ocorreu em $10 \%$ das amostras.

Tabela 1 - Índice de acerto do teste de determinação do sexo fetal pela análise molecular do plasma materno, de acordo com o gênero apontado e a idade gestacional.

\begin{tabular}{|c|c|c|c|}
\hline \multirow[b]{2}{*}{ Fase da gravidez (semanas) } & \multirow[b]{2}{*}{$\mathrm{n}$} & \multicolumn{2}{|c|}{ Resultado do teste (\%) } \\
\hline & & Feminino & Masculino \\
\hline$<8$ & 20 & 75,00 & 100 \\
\hline $8-12$ & 79 & 100 & 100 \\
\hline $13-17$ & 68 & 100 & 100 \\
\hline$>17$ & 45 & 100 & 100 \\
\hline Total & 212 & & \\
\hline
\end{tabular}

\section{Discussão}

O método de PCR trouxe nestes últimos 20 anos grandes contribuições às ciências biológicas, incluindo a medicina. Trata-se de técnica relativamente simples, rápida, barata e de grande sensibilidade. Este trabalho vale-se principalmente desta última característica, que deriva da amplificação exponencial de um fragmento de DNA, ao longo dos ciclos da reação. A definição do fragmento a ser amplificado tornou-se mais simples com os avanços das técnicas de seqüenciamento e os dados provindos dos diferentes projetos Genoma, disponibilizando o acesso às seqüências de DNA, empregadas na produção do reagente específico da PCR que são os primers.

A enorme sensibilidade da PCR permite detectar pequenas quantidades de DNA fetal presente no plasma materno. Este DNA provém de diferentes tipos de células fetais, mas no plasma materno ocorre enriquecimento deste DNA fetal, cuja quantidade aumenta conforme a evolução da gravidez $z^{7}$. No entanto, não é possível separar-se o DNA fetal do DNA materno igualmente presente no plasma, mas em maiores quantidades. Portanto, o diagnóstico do genótipo fetal só é possivel quando este for diferente do materno. No caso específico da sexagem fetal, não há necessidade de conhecimento do genótipo materno, a priori, já que obviamente mãe e filho diferem quanto à presença do cromossomo Y. Outra situação evidente é o caso de mães Rh negativas, pois sabe-se que este fenótipo é causado por deleção quase completa do gene $R h D$. Havendo a detecção deste gene inferese que o feto é Rh positivo ${ }^{15}$. Outras situações específicas irão provavelmente requerer a análise dos genótipos materno e paterno, para a execução e avaliação do teste ${ }^{16}$.

A determinação do sexo fetal vem sendo descrita por laboratórios de diferentes países, com resultados muito precisos ${ }^{17,18}$. Pesquisadores franceses trabalharam com 121 amostras de mulheres no primeiro trimestre da gravidez (média $=11,8$ semanas), obtendo $100 \%$ de concordância ${ }^{17}$, enquanto no Japão, o grupo de Sezikawa et al. ${ }^{18}$ analisou 302 amostras de mulheres com gravidez entre a $7^{\mathrm{a}}$ e a $16^{\mathrm{a}}$ semana, havendo erro em apenas 4 resultados, todos falso-negativos, ou seja, não se detectou a presença de DNA do cromossomo Y, mas o feto era masculino. Nestes casos as pacientes estavam com 9 (2 pacientes), 11 e 13 semanas de gestação, respectivamente.

Todos trabalhos ressaltam que se trata de técnica sujeita a variações, parte desta derivando dos métodos de coleta e preparo do DNA ${ }^{19}$, da escolha dos primers de PCR e da metodologia de PCR propriamente. A técnica aqui descrita teve que ser aprimorada ao longo de quatro anos até atingir o atual formato e indice de acerto descrito, permitindo seu uso rotineiro. 
Com a utilização de metodologias ainda mais rápidas e sensiveis de PCR, como o PCR em tempo real, devem-se obter índices de acerto ainda maiores, inclusive em fases precoces da gravidez, ou seja, antes da $8^{a}$ semana. Além disso, os resultados das pesquisas em curso no momento permitirão sem dúvida, no futuro próximo, o uso clínico destes testes, reduzindo a necessidade de técnicas invasivas de amostragem ${ }^{20}$.

\section{ABSTRACT}

Purpose: to evaluate a new method of fetal sex determination through the analysis of DNA from maternal plasma.

Methods: peripheral blood $(10 \mathrm{~mL})$ was drawn from pregnant women in different gestational ages. Plasma was separated and isolated DNA was submitted to the polymerase chain reaction $(P C R)$ with primers from the Y-chromosome-specific gene DYS14. Results: two hundred and twelve patients were enrolled. PCR results were compared to either confirmatory ultrasonography and/or birth. Agreement was observed in 209 samples. Discordant plasmas had a PCR result of female fetus and all of them were derived from mothers with less than 8 weeks of pregnancy.

Conclusion: the PCR method developed for fetal sex determination has excellent sensitivity and specificity, permitting its use as a routine test. A PCR result of male fetus presents a higher confidence than a female one, specially in early gestational periods. New applications employing fetal DNA from maternal plasma are being developed and hopefully will allow noninvasive diagnosis of several conditions.

KEYWORDS: PCR. Plasma DNA. Fetal sex determination.

\section{Agradecimentos}

Os autores agradecem aos Doutores Fábio Galucci e Alexandre Ades, que foram os primeiros colaboradores deste estudo. Agradecemos também todas as mães pela participação voluntária nesta pesquisa.

\section{Referências}

1. Walknowska J, Conte FA, Grumbach MM. Practical and theoretical implications of fetal/maternal lymphocyte transfer. Lancet 1969; 1:1119-22.

2. Lo YM, Patel P, Wainscoat JS, Sampietro M, Gillmer MD, Fleming KA. Prenatal sex determination by DNA amplification from maternal peripheral blood. Lancet 1989; 2:1363-5.

3. Bianchi DW. Current knowledge about fetal blood cells in the maternal circulation. J Perinat Med 1998; 26:175-85.

4. Chen XQ, Stroun M, Magnenat JL, et al. Microsatellite alterations in plasma DNA of small cell lung cancer patients. Nat Med 1996; 2:1033-5.
5. Anker P, Mulcahy H, Stroun M. Circulating nucleic acids in plasma and serum as a noninvasive investigation for cancer: time for large-scale clinical studies? Int J Cancer 2003; 103:149-52.

6. Lo YM, Corbetta N, Chamberlain PF, et al. Presence of fetal DNA in maternal plasma and serum. Lancet. $1997 ; 350: 485-7$.

7. Lo YM, Tein MS, Lau TK, et al. Quantitative analysis of fetal DNA in maternal plasma and serum: implications for noninvasive prenatal diagnosis. Am J Hum Genet 1998; 62:768-75.

8. Lo YM, Hjelm NM, Fidler C, et al. Prenatal diagnosis of fetal RhD status by molecular analysis of maternal plasma. N Engl J Med 1998; 339:1734-8.

9. Chiu RW, Lau TK, Leung TN, Chow KC, Chui DH, Lo YM. Prenatal exclusion of $\beta$-thalassaemia major by examination of maternal plasma. Lancet 2002; 360:998-1000.

10. Saito H, Sekizawa A, Morimoto T, Suzuki M, Yanaihara T. Prenatal DNA diagnosis of a singlegene disorder from maternal plasma. Lancet 2000; 356:1170.

11.Lo YM, Lau TK, Zhang J, et al. Increased fetal DNA concentrations in the plasma of pregnant women carrying fetuses with trisomy 21 . Clin Chem 1999; 45:1747-51.

12.Bischoff FZ, Sinacori MK, Dang DD, et al. Cell-free fetal DNA and intact fetal cells in maternal blood circulation: implications for first and second trimester non-invasive prenatal diagnosis. Hum Reprod Update 2002; 8:493-500.

13.Lo YM, Patel P, Sampietro M, Gillmer MD, Fleming KA, Wainscoat JS. Detection of single-copy fetal DNA sequence from maternal blood. Lancet 1990; 335:1463-4.

14.Saiki RK, Scharf S, Faloona F, et al. Enzymatic amplification of beta-globin genomic sequences and restriction site analysis for diagnosis of sickle cell anemia. Science 1985; 230:1350-4.

15.Zhong XY, Holzgreve W, Hahn S. Detection of fetal Rhesus D and sex using fetal DNA from maternal plasma by multiplex polymerase chain reaction. BJOG 2000; 107:766-9.

16.Gonzalez-Gonzalez MC, Garcia-Hoyos M, Trujillo MJ, et al. Prenatal detection of a cystic fibrosis mutation in fetal DNA from maternal plasma. Prenat Diagn 2002; 22:946-8.

17. Costa JM, Benachi A, Gautier E, Jouannic JM, Ernault P, Dumez Y. First-trimester fetal sex determination in maternal serum using real-time PCR. Prenat Diagn 2001; 21:1070-4.

18. Sezikawa A, Kondo T, Iwasaki M, et al. Accuracy of fetal gender determination by analysis of DNA in maternal plasma. Clin Chem 2001; 47:1856-8.

19. Chiu RW, Poon LL, Lau TK, Leung TN, Wong EM, Lo YM. Effects of blood-processing protocols on fetal and total DNA quantification in maternal plasma. Clin Chem 2001; 47:1607-13.

20.Pertl B, Bianchi DW. Fetal DNA in maternal plasma: emerging clinical applications. Obstet Gynecol 2001; 98:483-90.

Recebido em: 19/9/2003 Aceito com modificações em: 22/10/2003 